ERDC/TN EWN-21-1

November 2021

\title{
Engineering With Nature: The Role of Mangroves in Coastal Protection
}

\author{
by Tori Tomiczek, Anna Wargula, Nia Hurst,
}

Duncan Bryant, and Leigh Provost

PURPOSE: The purpose of this Engineering With Nature technical note (EWN TN) is to review previous studies of mangroves as a nature-based adaptation alternative for coastal protection and flood hazard mitigation.

INTRODUCTION: Coastal communities are threatened by chronic and acute flood hazards, including nuisance flooding during high tides and inundation and infrastructure damage from tropical cyclones or storms. These hazards are projected to intensify in the next $50 \mathrm{yr}^{1}$ due to sea level change and intensifying coastal storms compounded with growing population densities near US coastlines. Therefore, communities are challenged to develop sustainable, resilient adaptation strategies focused on coastal design alternatives that will allow these areas to mitigate the effects of coastal flooding.

A growing body of literature suggests that the appropriate implementation of natural and naturebased features (NNBF) can provide similar coastal flood protection as traditional grey strategies, those characterized by concrete or other hardened material structures. Bridges et al. (2018) showcase Engineering With Nature projects across the globe ranging from beaches and dunes, wetlands, reefs, and mangroves. NNBF provided ecological and social co-benefits and can self-adapt to rising seas and recover naturally following extreme events.

In particular, mangrove forests have been observed to provide significant protection during storm and tsunami events (e.g., Krauss et al. 2009; Alongi 2008; Das and Vincent 2009; Goda et al. 2019; Tomiczek et al. 2020a), mitigating inland water levels, wave heights, and damage to near-coast structures. However, the engineering performance of mangrove systems must be quantified to develop reliable design guidance for successful implementation. While several field, laboratory, and numerical studies detailed in the following sections have advanced the understanding of mangrove effects on wave transformation during overland flow events, additional work is required. This EWN TN (1) provides a brief background on mangrove habitat and characteristics, emphasizing species native to southern Florida; (2) details studies investigating coastal protection provided by mangrove forests through field observations and experiments, and physical model experiments; (3) describes documented ecological, economic, and social co-benefits of mangrove forests; (4) addresses knowledge and data gaps and areas for future work; and (5) summarizes conclusions of this literature review.

\footnotetext{
${ }^{1}$ For a full list of the spelled-out forms of the units of measure used in this document, please refer to US Government Publishing Office Style Manual, 31st ed. (Washington, DC: US Government Publishing Office 2016), 248-52, https://www.govinfo.gov/content/pkg/GPO-STYLEMANUAL-2016/pdf/GPO-STYLEMANUAL-2016.pdf.
} 
Mangrove Habitat and Characteristics. Mangroves are a group of woody halophyte species found in tropical and subtropical coastal regions. Their salt tolerance allows these plants to thrive in intertidal zones. Occupying over 13 million ha ${ }^{1}$ in marine and brackish environments, there are 54 valid species of mangroves worldwide; however, definitions differ based on physical and ecological traits, and over 80 mangrove species have been reported considering all plants that live in these environments (Feller 2018). Mangroves are intolerant to freezing temperatures and frost. Thus, their latitudinal range is limited to regions between $32^{\circ} \mathrm{N}$ and $38^{\circ} \mathrm{S}$, with ideal air temperatures between $21^{\circ} \mathrm{C}$ and $26^{\circ} \mathrm{C}$ (Quisthoudt et al. 2012). Global increases in temperature are expected to expand the mangrove range to higher latitudes, excluding other limiting factors (Gilman et al. 2008). Ellison et al. (2002) found that mangrove species diversity decreases with increasing latitude. Despite regularly occupying shorelines with salinities up to $40 \mathrm{ppt}$, mangroves are generally considered facultative halophytes and do not require saltwater for survival (Krauss and Ball 2013). However, there is still active research with evidence for characterizing mangroves as obligate halophytes (Wang et al. 2011). However, their salinity tolerance allows them to thrive in saline environments where limited freshwater and tidal influence minimize competition (USFWS 1999).

Optimal mangrove growth occurs in low-energy shorelines where fine-grained sand and sediment, such as clay and silt, can accumulate, resulting in muds with high organic matter. Mangroves can also be found on rock and shelly substrates, though they are often less productive in these conditions (Odum, McIvor, and Smith 1982; Mendelssohn and McKee 2000). All mangroves are viviparous, with seeds germinating into seedlings while still attached to the parent plant. Viviparity offers the reproductive advantage of seedling survival since high salinity, wave action, and oxygen-limited sediment can hinder seed germination. Once germinated, the mangrove propagules detach from the mangrove parent and are transported by wave action and currents to colonize new areas, remaining viable for rooting up to a year after detachment and sustaining themselves via photosynthesis. As growth is restricted under closed canopies due to the shade intolerance of mature mangroves, forests often consist of similarly aged trees.

Mangrove Adaptations. Mangroves are well suited for their water-logged, saline environments through a variety of adaptations. To survive in routinely flooded, anaerobic conditions, many mangroves have aerial roots to supply oxygen to belowground roots and facilitate gas exchange. Stilt roots (arched aerial prop roots), knee roots (above ground looping horizontal cable roots), and pneumatophores (vertical pencil-like offshoots of cable roots) are all aerial roots exhibited by mangrove species. Though aerial roots may vary physically from one mangrove species to another, they are functionally similar, taking oxygen directly from the atmosphere during anaerobic soil conditions and periods of inundation. Above-ground roots also aid tree stability, providing resistance against frequent wave forces. Above-ground roots have lenticels, or small openings, on the surface that facilitate $\mathrm{O}_{2}$ entry, which is then transported via aerenchyma, or porous tissue, to the belowground roots (Feller and Sitnik 1996). Oxygen can then be stored in the roots and used during periods of root submergence during high tide. To survive in high salinity conditions (up to hypersaline), mangroves have also developed salt-exclusionary and removal adaptations (Tomlinson 1986; USFWS 1999). Some mangroves, such as the black mangrove, remove salt after

\footnotetext{
${ }^{1}$ For a full list of the unit conversions used in this document, please refer to US Government Publishing Office Style Manual, 31st ed. (Washington, DC: US Government Publishing Office 2016), 345-7, https://www.govinfo.gov/content/pkg/GPO-STYLEMANUAL-2016/pdf/GPO-STYLEMANUAL-2016.pdf.
} 
intake by excreting it onto their leaves. Other mangroves, such as the white mangrove, exclude salt during initial water uptake. Additional adaptations for sunny tropical/subtropical environments allow mangroves to alter the orientation of their leaves to protect against sun damage and limit the opening of their stomata during the day to reduce evapotranspiration (Reef and Lovelock 2015).

At the beginning of the century, mangrove forests were estimated to cover 140,000-150,000 $\mathrm{km}^{2}$ of the earth's surface (Spalding et al. 2010; Giri et al. 2011). It is estimated that $35 \%$ of the total mangrove forest could have been lost in the 1980s and 1990s (Friess et al. 2019). Mangroves are often categorized by forest type: fringe, overwash, riverine, basin, and dwarf as described in Table 1 (Lugo and Snedaker 1974).

\begin{tabular}{|l|l|}
\hline \multicolumn{2}{|l|}{ Table 1. Summary of mangrove forest types. } \\
\hline Fringing Mangroves & $\begin{array}{l}\text { Found along open shorelines and lagoons that are regularly influenced by tidal activity } \\
\text { and wave action. Fringing mangroves are often exposed to storm surges and winds } \\
\text { and are typically the first line of defense against storms for mangrove dominated } \\
\text { coasts. }\end{array}$ \\
\hline Overwash Mangroves & $\begin{array}{l}\text { Persist on islands and are often completely flooded at high tide. Typically consist of } \\
\text { red mangroves (USFWS 1999). }\end{array}$ \\
\hline $\begin{array}{l}\text { Riverine/Estuarine } \\
\text { Mangroves }\end{array}$ & $\begin{array}{l}\text { Located along river floodplains and often fringed by red mangroves, they regularly } \\
\text { experience a combination of freshwater from riverine input and seawater from tidal } \\
\text { influence. These mangrove communities are some of the most highly productive } \\
\text { mangrove forest types due to enhanced nutrient and sediment deposition from tidal } \\
\text { exchange (USFWS 1999). }\end{array}$ \\
\hline Basin Mangroves & $\begin{array}{l}\text { Occur in depressions near inlets. Those near the coast receive tidal exchange but } \\
\text { often consist of slow-moving or stagnant water, resulting in high salinities and } \\
\text { anaerobic soils. Though often dominated by black and white mangroves, red } \\
\text { mangroves dominate when closer to shorelines (Odum, Mclvor, and Smith 1982). }\end{array}$ \\
\hline Dwarf/Scrub Mangroves & $\begin{array}{l}\text { Typically contain trees less than 1.5 m in height. Their stunted growth is usually due to } \\
\text { a lack of nutrients, extremely low or high salinities, or rocky/shell-ridden substrates } \\
\text { (USFWS 1999). }\end{array}$ \\
\hline
\end{tabular}

Florida Mangroves. In the continental United States, mangrove forests occur predominantly between $24.5^{\circ} \mathrm{N}$ and $26^{\circ} \mathrm{N}$ latitude, along the coastlines of the northern Gulf of Mexico in Florida, Louisiana, and Texas, and on the Atlantic coast of Florida. There are approximately $\sim 250,000$ ha of mangroves in the United States, with over 98\% occurring in Florida and the majority of that percentage occurring in south Florida. (Giri and Long 2016). The northernmost limit of mangroves is $30^{\circ} \mathrm{N}$ in Florida, a threshold set due to intolerance of freezing temperatures $\left(\leq 0^{\circ} \mathrm{C}\right)$ and extreme freezing conditions $\left(<-4^{\circ} \mathrm{C}\right)$ (Cavanaugh et al. 2013).

In south Florida and the Florida Keys $\left(\sim 24^{\circ} \mathrm{N}-27^{\circ} \mathrm{N}\right)$, three species occupy an area of $2000 \mathrm{~km}^{2}$ (FDEP 2019). These species include Rhizophora mangle (red mangrove, Figure 1), generally found seaward of other mangrove types; Avicennia germinans (black mangrove), found slightly inland and at higher elevations than red mangroves; and Laguncularia racemosa (white mangroves), found farthest inland and at the highest elevations of the three species. Buttonwood trees (Conocarpus erectus), an associate mangrove, is not technically a true mangrove but is often 
found along the upper fringe of mangrove forests. These dominant species occupy the entire intertidal gradient from just above the lowest intertidal zone to the high-tide mark.

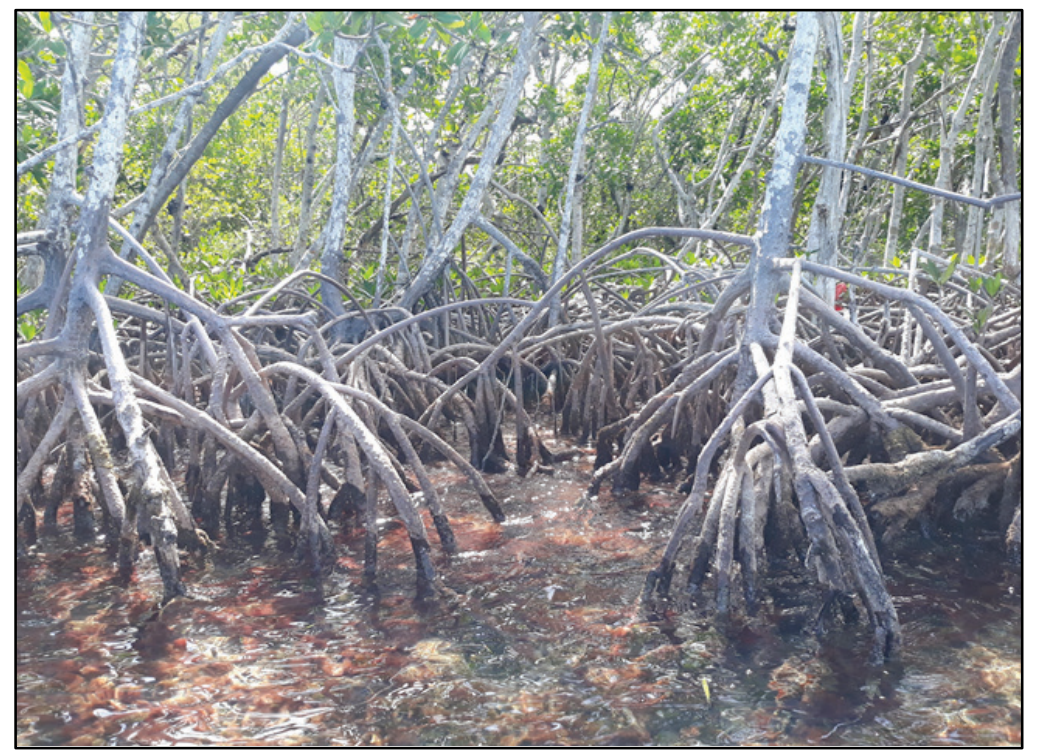

Figure 1. Red mangroves, Islamorada, FL, USA.

Red Mangrove (Rhizophora mangle). R. mangle-dominated forests are located on the lower to mid-intertidal zone along shoreline edges. Experiencing frequent tidal inundation, red mangroves have prop roots that provide stability and supply oxygen to the root zone. Their roots are capable of excluding $90 \%-97 \%$ of salt upon water intake and can survive in salinities up to 65 ppt (Odum, McIvor, and Smith 1982). Red mangroves average $6 \mathrm{~m}$ tall in Florida but can achieve heights up to $25 \mathrm{~m}$ in highly productive areas (USFWS 1999).

Black Mangrove (Avicennia germinans). The black mangrove is the most common mangrove in Florida outside of the Everglades and is also the most cold tolerant, existing farther north than either other species (Mendelssohn and McKee 2000). Black mangroves persist at a slightly higher elevation than red mangroves and are often found in the upper intertidal zone, occasionally experiencing flooded conditions. Their horizontal, cable roots extrude pneumatophores, stick-like aerial roots, up to $30 \mathrm{~cm}$ above the soil surface to provide oxygen to the root zone (Odum, McIvor, and Smith 1982). Black mangroves can withstand salinities as high as 90 ppt by selectively excreting salt to outer leaves (Odum, McIvor, and Smith 1982). Black mangroves achieve heights up to $20 \mathrm{~m}$ but are typically smaller in Florida, while their heights vary between 1.5 and $10 \mathrm{~m}$ in Louisiana (Houck and Neill 2009).

White Mangrove (Laguncularia racemosa). White mangroves are typically found at higher elevations than either black or red varieties and are rarely flooded. Although they often lack visible roots, they can produce prop roots if flooded for long periods or experience anaerobic soil conditions. White mangroves are the shortest of the three Florida species (maximum height of $15 \mathrm{~m}$ ) and are also the least cold tolerant; they are more common to south Florida than anywhere else in the state (Odum, McIvor, and Smith 1982; USFWS 1999). They can survive in salinities upwards of 90 ppt, removing salt through excretion (Odum, McIvor, and Smith 1982). 
The combination of rising sea levels, saltwater intrusion, and milder winters induced by climate change are expected to expand the range of mangrove forest habitats in Florida. There is evidence that mangroves in Florida are experiencing landward migration, encroaching upon saltmarsh habitat due to their ability to adapt to increasing occurrences of inundation, sea level rise, and salinity (Saintilan et al. 2020; Giri and Long 2016; Steinmuller et al. 2019). Similarly, milder winters and decreased extreme cold events may lead to the northern expansion of mangroves (Cavanaugh et al., 2013; Giri and Long, 2014; Giri and Long 2016). The black mangrove is the most cold-tolerant Florida species and responsible for the majority of the presumed poleward expansions observed. Mangrove expansion and encroachment into salt marshes can increase carbon storage in mangroves forests, which store $2 \times$ more carbon per area compared to salt marshes (Doughty et al. 2016; Breithaupt et al. 2020). High sedimentation rates, significant peat accumulation from biomass production, and minimal decomposition due to a lack of oxygen make mangroves highly efficient at carbon capture and storage. Mangrove ecosystems are a main component of blue carbon storage, defined as carbon stored in coastal marine environments (McLeod et al. 2011). Although mangroves occupy a small percentage (0.5\%) of coastal areas around the world, they are estimated to provide $10 \%-15 \%$ of the coastal sediment carbon storage (Alongi 2014). These reports are consistent with other studies that measured stored carbon in mangrove forests and suggest that these forests are among the most carbon-rich forests in the world, storing 2-3× more carbon than any other forest type (Fujimoto et al. 1999; Donato et al. 2011; Alongi 2014). Breithaupt et al. (2020) found that mangroves in southwest Florida buried 1.9-2.3× more carbon than salt marshes. Mangrove expansion may also improve coastal protection as they have higher wave attenuation benefits compared to saltmarshes (Chmura 2003).

Red Mangrove Characteristics. Mangrove characteristics vary with species and location. Red mangroves ( $R$. mangle) trunk diameters are typically measured at a height $1.3 \mathrm{~m}$ above ground (termed diameter at breast height $(\mathrm{DBH})$ or girth at breast height). Measurements of DBH in mangrove forests have been reported between 4.5 to $16.5 \mathrm{~cm}$ in Cuddalore, India (Danielson et al. 2005) and 9 to $75.5 \mathrm{~cm}$ in the Matang Mangrove Forest Reserve Malaysia (Jin Eong et al. 1995), with greater DBH indicative of a more mature tree. Stem densities also vary by location and forest age. In the United States, Dawes et al. (1999) reported a mean density of $0.504 \mathrm{stems} / \mathrm{m}^{2}$ for primarily $R$. mangle mangrove forests in Tampa Bay, FL. Novitzky (2010) performed a detailed field study of red mangrove characteristics in Rookery Bay, Cockroach Bay, and Crystal Bay, FL. The author measured DBH and stem density at each of the three field sites; average mangrove trunk diameters ranged from 3.18 to $12.74 \mathrm{~cm}$ while stem densities ranged from 0.86 to 2.02 stems $/ \mathrm{m}^{2}$. These values were similar to those measured by Tomiczek et al. (2019), who measured red mangrove trunk diameters, prop root densities, and prop root elastic moduli at three field sites in Key West, FL. While $R$. mangle are distinguished by their complex system of aerial prop roots that emerge from the trunk and anchor the tree into the ground (Figure 1), A. germinans contain aerial roots, pneumatophores, that grow vertically from the ground. Still, the roots of L. racemosa are found below ground.

General mangrove restoration guidance typically results in denser forests than found in natural forests. Guidance documents recommend planting propagules with $25-300 \mathrm{~cm}$ spacing between stems (Kainuma et al. 2013; EAD 2015). These documents recommend thinning restored forests to $1500-2000$ stems/ha (Clough et al. 1999; EAD 2015); the oldest forests may thin to 1,000 stems/ha (EAD 2015). Imbert, Rousteau, and Scherrer (2000) suggest red mangroves are best suited for low- 
lying, sheltered shorelines, and propagules should be planted at the beginning in July/August, coinciding with the beginning of the rainy season and when propagules are widely available.

\section{POST-DISASTER OBSERVATIONS AND MODELING OF MANGROVE EFFECTS:}

Observations or numerical hindcasts following tsunami or major storm events (e.g., tropical cyclones) have demonstrated the capacity of mangroves to protect life and property during extreme hydrodynamic conditions. Post-impact surveys of areas affected by the 2004 Indian Ocean earthquake and tsunami indicated that mangrove forests provided significant protection to inland communities (Alongi 2008). Chang et al. (2006) synthesized satellite imagery, georeferenced videos and photographs, field observations, and resident interviews from 20 villages along the Andaman Coast, Thailand. Similarly, they reported that mangroves were an effective buffer during the 2004 tsunami. Danielsen et al. (2005) studied the effects of this tsunami in the Cuddalore District in India, finding that areas with dense mangrove forests $(1,400-2,600$ trees/ha) were significantly less damaged than other areas. More recently, Goda et al. (2019) observed structures behind mangroves of moderate cross-shore forest thickness experienced less damage than unsheltered structures for $\sim 2 \mathrm{~m}$ high tsunami waves in Palu Bay, Sulawesi, Indonesia, indicating that even forests of moderate cross-shore thickness can provide noticeable protection against tsunami impacts. In a case study of tsunami inundation of the same event in Palu Timur, Sulawesi, Indonesia, Novitarima and Saputri (2019) found that adding 0.073 ha of mangrove forest could reduce the tsunami inundation area by over $50 \%$.

Observations following tropical cyclones have similarly indicated the protective value of mangrove systems. Das and Vincent (2009) investigated 409 villages affected by the 1999 Indian Super Cyclone. Using statistical regressions, the authors found that villages shielded by mangroves with wider cross-shore forest thicknesses between the village and the coast experienced significantly fewer deaths than villages with no or few mangroves. Mangroves were observed reducing water levels during Hurricane Charley and Wilma along coastal Florida (Krauss et al. 2009), and Tomiczek et al. (2020a) surveyed damage to structures and shorelines in the Florida Keys following Hurricane Irma (2017). The structures sheltered by moderate widths of mangrove shoreline consistently experienced more minor damage than neighboring structures with other shoreline archetypes. While mangroves provide protection during extreme events, they are also vulnerable to damage from extreme inundation, waves, and particularly wind. Several studies have documented damage to these systems following hurricanes and intense storms (e.g., Tallie et al. 2020); however, in less severe cases, these forests may be able to self-recover (e.g., Alongi 2008; Danielson et al. 2017; Asbridge et al. 2018), pointing to their resilience as a coastal infrastructure system.

In addition to post-event observations, numerical simulations allow for comparison of impacts with and without natural infrastructure to coastal protection as well as the degree of impact at regional and global scales. Guannel et al. (2016) investigated individual and combined protection by mangroves, coral reefs, and seagrasses during non-storm and storm conditions using a numerical model of synthetic hurricane wind, waves, and storm surge over one-dimensional idealized transects. Results indicated that mangroves reduced wave heights by $70 \%$ and that multiple habitats provided more benefits than any individual system. Similarly, a meta-analysis of 69 coastal habitats including coral reefs, mangroves, seagrasses, kelp beds, and salt marshes indicated that mangrove projects provided up to $50 \%$ improvement in protection during storm events when considering damage costs from storms (Narayan et al. 2016). The authors posited that these systems were cheaper to install than submerged breakwaters providing similar protection. 
Finally, Zhang et al. (2012) compared field measurements of storm surge due to Hurricane Wilma in southern Florida to numerical results of inundation from the Coastal and Estuarine Storm Tide model, finding that $6-30 \mathrm{~km}$ mangrove forests significantly reduced inundation area and storm surge levels inland. However, many developed areas require adequate coastal protection in a confined cross-shore area. While several studies have suggested that moderate cross-shore forest thicknesses can provide noticeable protection (Goda et al. 2019; Tomiczek et al. 2020a), a better understanding of the required width of a mangrove forest with a given density is needed to implement these systems in coastal design effectively.

Finally, an innovative study conducted in collaboration with University of California Santa Cruz, Risk Management Solutions, and The Nature Conservancy used an insurance industry catastrophe model to quantify the economic benefits of mangroves in Florida for reducing coastal flood damages annually in Collier County, FL, and from Hurricane Irma. Annually, across multiple storms, mangroves reduced flood damages by $25.5 \%$ to properties behind them in Collier County. During Hurricane Irma, 626,000 people living behind mangroves saw reduced flooding across Florida, resulting in $\$ 1.5$ billion of averted surge-related flood damages or an average of $\$ 7,500$ in risk reduction benefits per hectare of mangroves with properties behind them (Narayan et al. 2019).

FIELD EXPERIMENTS OF WAVE ATTENUATION THROUGH MANGROVES: Table 2 summarizes previous field campaigns measuring wave attenuation by mangrove forests, including location of study, mangrove species, and wave type.

\begin{tabular}{|l|l|l|l||}
\hline \multicolumn{3}{|l|}{ Table 2. Summary of field studies of wave attenuation through mangrove forests. } \\
\hline \hline Study & Location & Species & Wave Type \\
\hline Mazda et al. (1997) & $\begin{array}{l}\text { Tong King Delta, } \\
\text { Vietnam }\end{array}$ & Kandelia candel & short-period (5-8 s) \\
\hline Quartel et al. (2007) & $\begin{array}{l}\text { Red River Delta, } \\
\text { Vietnam }\end{array}$ & Kandelia candel & short-period (3-7 s) \\
\hline Bao (2011) & $\begin{array}{l}\text { Red River Delta and } \\
\text { Can Gio reserve, } \\
\text { Vietnam }\end{array}$ & $\begin{array}{l}\text { mixed (Aegiceras corniculatum, } \\
\text { Avicennia marina, Rhizophora } \\
\text { mucronata, Sonneratia caseolaris, } \\
\text { Kandelia candel) }\end{array}$ & short-period \\
\hline Horstman et al. (2014) & $\begin{array}{l}\text { Andaman region, } \\
\text { Thailand }\end{array}$ & $\begin{array}{l}\text { mixed (Avicennia sp., Sonneratia } \\
\text { sp., Rhizophora sp.) }\end{array}$ & short-period (3-19 s) \\
\hline Trung et al. (2015) & $\begin{array}{l}\text { Cai Lon River and } \\
\text { Ong Doc River, } \\
\text { Vietnam }\end{array}$ & Rhizophora apiculata & boat wakes \\
\hline Thuy et al. (2017) & $\begin{array}{l}\text { Ca Mau River, } \\
\text { Vietnam }\end{array}$ & Rhizophora apiculata & boat wakes \\
\hline Ismail et al. (2017) & $\begin{array}{l}\text { Matang Forest } \\
\text { Reserve, Malaysia }\end{array}$ & $\begin{array}{l}\text { mixed (Rhizophora sp. and } \\
\text { Bruguiera sp.) }\end{array}$ & boat wakes \\
\hline Tomiczek et al. ${ }^{1}$ & $\begin{array}{l}\text { Key West, Florida, } \\
\text { USA }\end{array}$ & Rhizophora mangle & boat wakes \\
\hline
\end{tabular}

\footnotetext{
${ }^{1}$ Tomiczek, T., A. Wargula, K. O'Donnell, V. LaVeck, K. Castagno, and S. Scyphers. In preparation. "Vesselgenerated wake attenuation by Rhizophora mangle in Key West, FL." Estuarine, Coastal, and Shelf Science.
} 
As indicated in the table, measurements generally focused on attenuation of recreational boatgenerated wakes or short-period waves generated by wind or swell (as opposed to long-period tsunami). Mazda et al. (1997) found that sites with primarily young mangroves showed little/no impact on wave transformation, while in areas where trees were sufficiently tall (6 yr old, vegetation parameters not provided), waves were reduced by up to $20 \%$ over a $100 \mathrm{~m}$ transect. Attenuation in these sites remained large even when water depth increased. Quartel et al. (2007) studied wave attenuation in coastal forests dominated by Kandelia candel (a species in the Rhizophoricae family). They proposed an equation for calculating the drag coefficient of a mangrove system as an exponential function of submerged projected underwater area. Similarly, Horstman et al. (2014) proposed relationships between vegetation densities, wave attenuation rates, sediment characteristics, and sedimentation rates. The authors noted that wave attenuation rates in areas dominated by dense Rhizophora vegetation were up to $0.012 / \mathrm{m}$ and that wave attenuation rates facilitated net sediment deposition in mangrove forests. Bao (2011) measured wave attenuation in 32 mangrove plots in coastal Vietnam and found that wave height decayed exponentially with distance. The author developed a "V-index" for characterizing mangrove plots by their ability to dissipate waves and proposed equations to determine the minimum vegetation band width required to attenuate waves to a safe wave height.

Studies of small recreational boat wakes have shown similar wave height reduction by mangrove forests. Trung et al. (2015) and Thuy et al. (2017) measured ship wake attenuation by riverine mangroves in Vietnam and found significant wave height reduction within moderate cross-shore distances. Trung et al. (2015) reported wave height reductions of $44 \%-56 \%$ and $70 \%-84 \%$ within $4 \mathrm{~m}$ and $10 \mathrm{~m}$, respectively, while Thuy et al. (2017) supplemented field results with a twodimensional Boussinesq numerical modeling and estimated that $200 \mathrm{~m}$ long timber piling combined with a $20 \mathrm{~m}$ wide mangrove fringe reduced runup and forces by $61 \%$ and $95 \%$, respectively. Ismail et al. (2017) measured reduction of wave amplitudes in a mixed mangrove forest and reported average reduction of wave amplitude by $63 \%$ over a $15 \mathrm{~m}$ transect. This reduction in wave amplitudes was similar to values reported by Tomiczek et al. ${ }^{1}$ based on measurements of 236 events of boat-generated wave heights throughout a $12.5 \mathrm{~m}$ wide mangrove island in Cow Key Channel between Key West and Stock Island, FL.

PHYSICAL MODELS OF MANGROVE EFFECTS ON WAVE PROPAGATION: Trees including mangroves have been modeled as rigid vegetation, contrasting with studies of wave transformation through flexible vegetation including cordgrass (Spartina), rush (Juncaceae), or seagrass (Thalassia testudinum, Posidonia oceanica and Zostera marina) (Anderson and Smith 2014; Ozeren et al. 2014; Lara et al. 2016; Lei and Nepf 2019). For example, Huang et al. (2011) used rigid, emergent cylinders to mimic mangroves to investigate solitary wave propagation using both physical model experiments and numerical model simulations. More recently, several studies have specifically investigated the effects of the characteristic prop roots of the Rhziophora species (Table 3) on hydrodynamics. These tests have been conducted at a range of scales and under constant flow and for long- and short-period wave conditions. These studies also sought to improve the representation of the Rhziophora species by moving away from the use of rigid cylinders to a representative geometric form. Based on field measurements at 18 sites in Vietnam, Ohira et al. (2013) presented a method for parameterizing the Rhizophora prop root system including diameter,

\footnotetext{
${ }^{1}$ Tomiczek, T., A. Wargula, K. O'Donnell, V. LaVeck, K. Castagno, and S. Scyphers. In preparation. "VesselGenerated Wake Attenuation by Rhizophora Mangle in Key West, FL." Estuarine, Coastal, and Shelf Science.
} 
number, height, and horizontal spreading of prop roots based on the specimen trunk diameter. This parameterization has been used to create mangrove mimics for several recent physical model experiments (Maza et al. 2017, 2019; Tomiczek et al. 2020b).

\begin{tabular}{|c|c|c|}
\hline Study & Scale & Hydrodynamic Conditions \\
\hline Strusińska-Correia et al. (2013) & $1: 20$ & solitary, tsunami bore \\
\hline Zhang et al. (2015) & $1: 7.5$ & constant flow \\
\hline Maza et al. (2017) & $1: 12$ & constant flow \\
\hline Chang et al. (2019) & $1: 7$ & regular \\
\hline Maza et al. (2019) & $1: 6$ & regular, irregular \\
\hline Tomiczek et al. (2020b) & $1: 16$ & $\begin{array}{l}\text { long waves, long waves over the constant } \\
\text { flow }\end{array}$ \\
\hline $\begin{array}{l}\text { Bryant et al. (experiments in progress } \\
\text { at ERDC) }\end{array}$ & $1: 2$ & regular, irregular \\
\hline $\begin{array}{l}\text { Kelty et al. (experiments in progress at } \\
\text { Oregon State University) }\end{array}$ & $1: 1$ & regular, irregular \\
\hline
\end{tabular}

Strusińska-Correia et al. (2013) reported transmission rates of $20 \%$ based on measurements of solitary wave and tsunami bore propagation through a 1:20 scale model of a mangrove trunk-prop root system. Zhang et al. (2015) constructed a 1:7.5 scale physical model based on field measurements and measured flow velocities, Reynolds numbers, and turbulent kinetic energy through the mangrove forests. The authors calculated drag coefficients from laboratory experiments that were consistent with field measurements. Chang et al. (2019) used a threedimensional (3D) printed mangrove prop root model at 1:7 scale and calculated inertial and drag coefficients for mangrove models subject to regular waves with periods between 1.25 to $1.70 \mathrm{~s}$ and heights between 1.83 to $4.02 \mathrm{~cm}$ propagating over two water depths $(10 \mathrm{~cm}$ and $19.5 \mathrm{~cm})$. A nonnegligible inertial effect was observed, and relationships were proposed for estimating the drag and inertial coefficients based on the Keulegan-Carpenter and Reynolds numbers.

Maza et al. (2017) and Maza et al. (2019) used the parameterization presented by Ohira et al. (2013) to construct a 1:12 scale and 1:6 scale model of a mature Rhizophora mangrove forest, respectively. In the former study, the results indicated velocities decreased by up to $50 \%$ within the root zone. In the later tests, the authors considered a stem density of 625 trees/ha (full scale) and measured wave attenuation and wave-induced forces on mangroves for short-period (regular and irregular) wave conditions. Water depth, wave height, and frontal area of the mangroves were identified as important parameters in determining short-period wave decay through the forest.

Tomiczek et al. (2020b) considered a similar parameterization as well as field measurements from the Florida Keys to create a 1:16 scale mimic of the Rhizophora trunk-prop root system (Figure 2). The authors measured flow transformation and load reduction on an idealized inland structure sheltered by two forest thicknesses compared to no-mangrove conditions; mangrove models were spaced $0.17 \mathrm{~m}$ (trunk center to trunk center) in the cross-shore and $0.19 \mathrm{~m}$ in the 
alongshore, representing a prototype density of 1,700 trees/ha. The authors found a relationship between load reduction and cross-shore mangrove thickness normalized by wave representative time scale and offshore celerity.

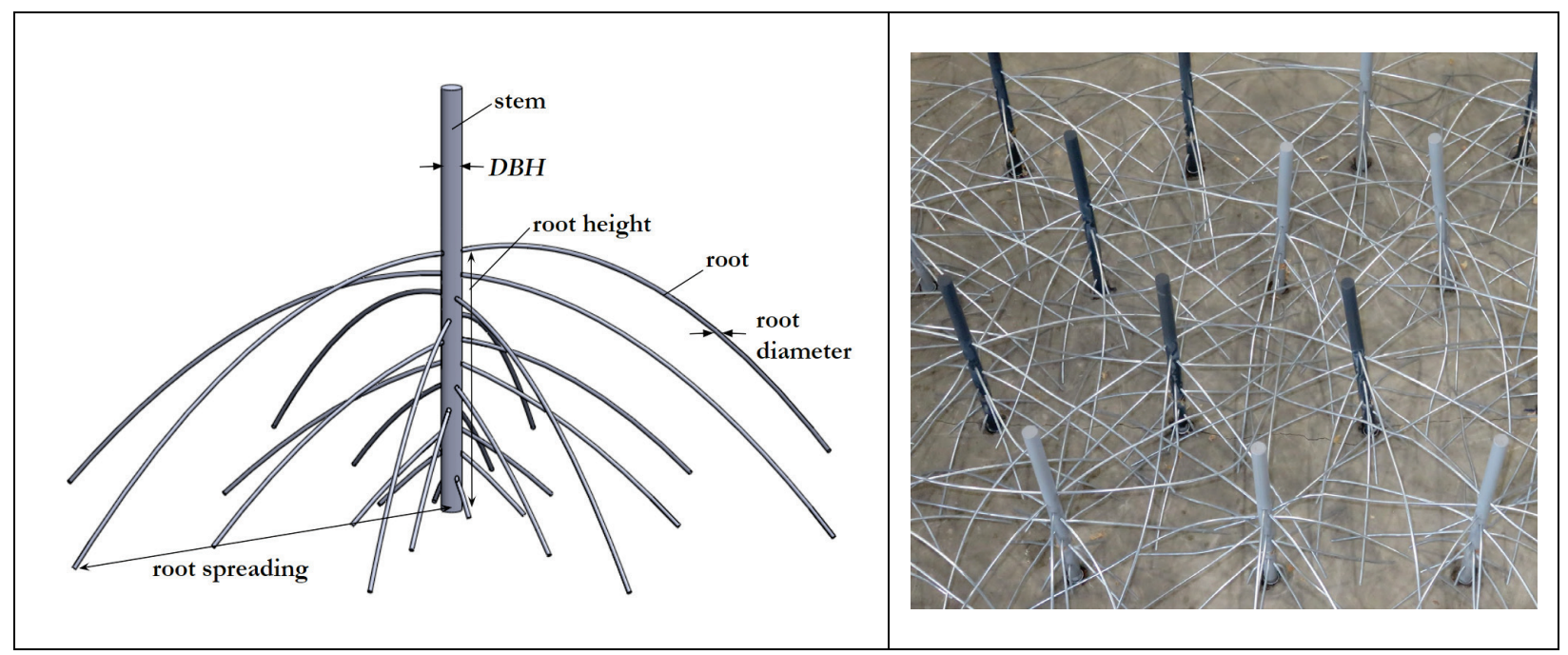

Figure 2. R. mangle physical model for DBH of $20 \mathrm{~cm}$ informed by Ohira et al. (2013) parameters (Tomiczek et al. 2020b).

These data were compared to simulations by the numerical model IH Cantabria's OpenFoam by Maza et al. (2015), who found that for similar stem densities, there was little effect of random or regular distribution of the cylinders on wave damping.

Another consideration that has been investigated is the effect of patchiness in coastal forests. Irish et al. (2014) investigated tsunami propagation through two configurations of rigid polyvinyl chloride pipe representing a patchy coastal forest. The authors found that momentum flux decreased in wake regions behind roughness patches and increased between patches due to channelization. Maza et al. (2016) performed experiments of solitary wave propagation through patchy rigid vegetation using rigid cylinders representing Avicennia mangroves. The authors similarly noted variability of force magnitude and direction owing to patchiness. Maza et al. (2016) observed more significant attenuation rates for more considerable wave heights and shorter wave periods and proposed a new parameter for estimating wave dissipation based on the effective length and submergence of the vegetation patch.

Ongoing experiments at the US Army Engineer Research and Development Center (ERDC) in Vicksburg, MS, are constructing a 1:2 scale model mangrove forest (Figure 3) based on measurements of $R$. mangle in Rookery Bay, FL, by Novitzky (2010). These experiments will be complemented with similar tests conducted at full scale in the Oregon State University wave flume to investigate cross-scale and cross-facility comparisons of mangrove density, incident hydrodynamic conditions, and scaling effects on flow transformation and load reduction. 


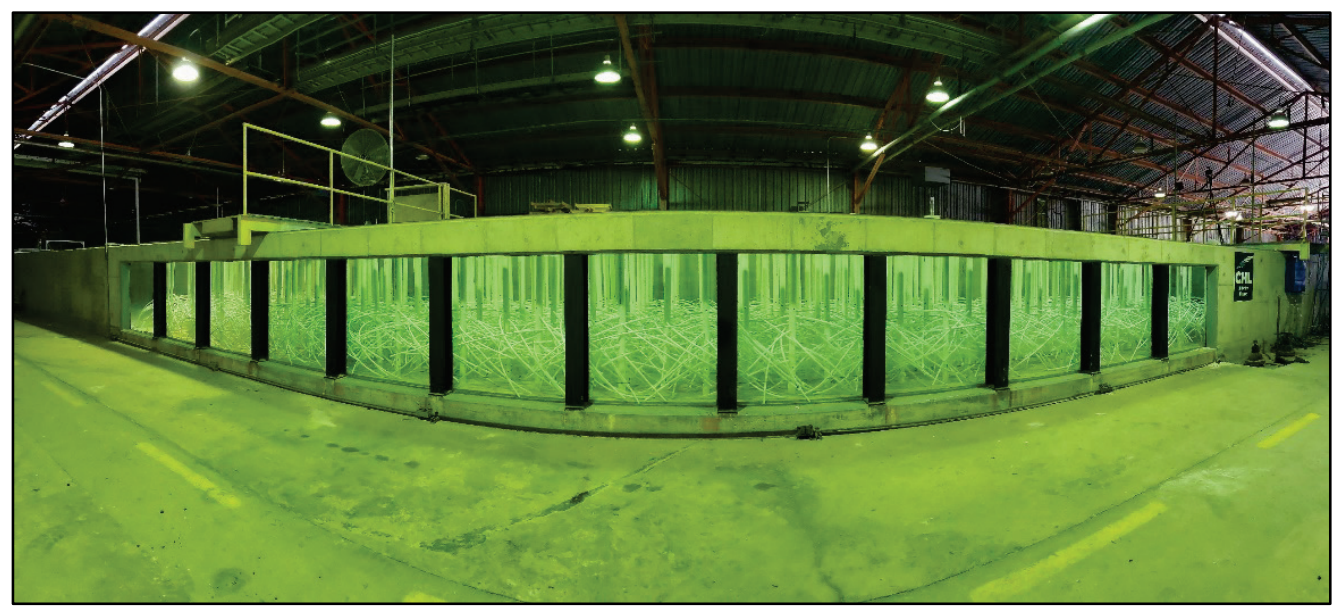

Figure 3. 1:2 R. mangle physical model constructed at the ERDC.

The field observations and physical model results provide predictive capability through the development of theoretical models for wave propagation through flexible and rigid vegetation (Dalrymple et al. 1984). The National Academy of Sciences (NAS 1977) proposed a transmission coefficient dependent on vegetation parameters (drag coefficient (order unity), wetted height, mean effective diameter, spacing, and width) and incident wave conditions (water depth, incident wave height) considering energy losses due to drag forces on an element oscillating in still water, combined with wave energy flux relationships, for waves propagating over a vegetated field. Similarly, Mendez and Losada (2004) presented a widely accepted empirical model for random wave transformation over vegetated fields, estimating wave height dissipation as a function of incident wave characteristics, geometry of vegetation stems, physical properties of the vegetation, and a drag coefficient specific for each plant. Despite these advances, all of the models require laboratory and/or field data to provide a drag coefficient, highlighting the need for in situ measurements and laboratory models. More information on these theoretical approaches is provided by Anderson et al. (2011) in a comprehensive literature review of wave dissipation by vegetation.

CO-BENEFITS OF MANGROVE FORESTS: While the aforementioned studies and observations relate to the engineering performance of mangrove forests in wave attenuation and protection of coastlines and near-coast infrastructure, mangroves are also known to provide environmental, ecological, and social/economic co-benefits. Vo et al. (2012) conducted a review of ecosystem services provided by mangroves and provided a detailed description of how ecosystem functions related to goods and services. The authors highlighted values of mangroves for direct use (i.e., timber, fiber, fuel, medicine, education, recreation, and cultural), indirect use (i.e., watershed protection, nutrient cycling, air pollution reduction, microclimate reduction, carbon storage), option (i.e., future direct and indirect use opportunities), and existence (i.e., biodiversity, cultural heritage). Additionally, mangroves provide valuable habitat for juvenile fish, shrimp, other crustaceans, mollusks and invertebrates, birds, insects, monkeys, and reptiles (McLeod and Salm 2006). Since mangroves span the entire intertidal zone, from regularly to only occasionally flooded, they offer diverse habitats for aquatic and terrestrial species. Mangroves provide food, habitat, and shelter for over 1,300 permanent, temporary, and opportunistic species (Odum, McIvor, and Smith 1982; USFWS 1999). In Florida, mangrove roots serve as rigid substrates for sessile shellfish, such as oysters and mussels, and provide critical nursery habitat 
and protection for juvenile fish. Over 200 fish species make their home in Florida mangroves, with over $90 \%$ of commercial and $70 \%$ of sport fisheries in Florida using mangroves for habitat, shelter, or food during some part of their lifecycle (Lewis et al. 1985; Ueland 2005). Nearly 200 species of birds utilize Florida mangroves for foraging, nesting, and protection (Ueland 2005). These habitats provide feedbacks and social benefits as communities around the world leverage these resources provided by the forests for income (Hussain and Badola 2010; Reinisch 2014) and social capital (Situmorang 2018). Hussain and Badola (2010) conducted structured surveys in India and reported that mangrove resources, including fisheries, timber, and others, contributed to over $14.5 \%$ of household income.

The complex above-ground root structures of mangroves help slow water velocity within forests, resulting in high sedimentation rates that help stabilize shorelines and prevent erosion (Katherisan 2003). Previous studies have found mangroves can retain up to $80 \%$ of sediment delivered to their systems during spring high tide events (Furukawa, Wolanski, and Mueller 1997). Red mangroves prop roots have increased sedimentation and wave attenuation values than bare substrates and other Florida mangrove species due to their position in the lower intertidal zone (Furukawa and Wolanski 1996; Krauss, Allen, and Cahoon 2003). However, mixed stands of black and red mangroves have higher sediment trapping capacities than a single species due to the increased complexity of both prop and pneumatophores (black) (Furukawa and Wolanski 1996; Kathiresan 2003). Hurricanes and storms also provide significant pulses of sediment to coastal and riverine mangroves. Breithaupt et al. (2019) evaluated the sedimentation impact of Hurricane Irma in southwest Florida and found a 3.02-4.31 cm sediment deposition layer, equivalent to the yearly accretion rate for the site in a singular event (Breithaupt et al. 2017). In conjunction with sediment deposition from marine and riverine sources, mangroves build elevation via peat deposition and organic matter accumulation, which can accrete to several meters thick (Feller and Sitnik 1996; USFWS 1999; Donato et al. 2011). While Alongi (2008) suggested that the rate of sedimentation in mangroves is close to rates of sea level rise, others have asserted that these fragile ecosystems require a sustained sediment supply and suitable conditions for accretion and that accelerating rates of sea level rise may be a threat to mangrove forest survival over decadal-scale climate change impacts (Cheong et al. 2013; Saintilan et al. 2020).

Mangroves express resiliency to storm events, despite experiencing defoliation, stem breakage, and uprooting. Aerial roots help maintain mangrove tree stability, while the retention of large reserves of belowground nutrients provides a nutrient subsidy after disturbance events to help stimulate productivity (Feller and Sitnik 1996; Kumara et al. 2010). Armitage et al. (2020) observed regrowth on damaged black mangrove branches in Texas just 2 months after injury from Hurricane Harvey, a category 4 storm. Severely damaged and defoliated mangroves in the Philippines saw a 90\% recovery in primary production 18 months after Super Typhoon Haiyan (Long et al. 2016). In Florida, mangroves in the Everglades National Park recovered their net primary production in fewer than 5 years after severe defoliation damage caused by Hurricane Wilma (Danielson et al. 2017). Recovery after storm events is facilitated by regeneration mechanisms, such as resprouting on surviving trees (black and white mangroves), the growth of propagules released by storm impacts (red mangroves), or via the expansion of understory trees saplings established pre-disturbance (Baldwin et al. 2001). Stems below the water line tend to be buffered by the water and are spared significant storm impacts (Armitage et al. 2020). 
KNOWLEDGE GAPS: While the aforementioned studies have improved the understanding of wave dissipation through rigid vegetation, knowledge gaps remain and require further investigation for the development of robust design guidance for implementing mangroves as coastal protection. Previous physical and numerical experiments considered an idealized, parameterized model of a scaled mangrove system; therefore, scaling effects from model to prototype scale on fluid-vegetation interaction must be identified and addressed to contextualize experimental results and implications for stakeholders. For example, many experiments consider only the trunk-prop root system of a mangrove forest, ignoring canopy effects and morphological evolution of the mangrove bed. Recently, Kalloe (2019) performed manual measurements and 3D laser scans to investigate wave damping potential of willow forests and compared results to measurements from full-scale experiments with live willow trees. The author found that wave dissipation in tests considering leaves in the tree canopy were $2 \%-4 \%$ higher than dissipation in tests considering canopy branches without leaves. While effects of leaves have been reported to be small (e.g., Kalloe 2019), canopy branches and leaves may become important when considering extreme storm surge levels or the combined effects of wind and hydrodynamic hazards. Including realistic bathymetries consistent with the sediment capture of mangrove prop roots will improve the understanding of wave evolution through these systems.

Standardized performance metrics must be defined to quantify the efficacy of mangroves in reducing inland hydrodynamic conditions including wave heights, velocities, and momentum flux as well as the effect on wave overtopping, runup, and loading on inland structures. These performance metrics may be dependent on mangrove forest density, diversity, forest width to wavelength ratio, incident wave height and steepness, and other parameters that must be identified for use in design. Furthermore, the contributing effects of natural and artificial infrastructure for hybrid system design must be more thoroughly investigated. Wave attenuation by natural and nature-based features combined with that by structural systems (e.g., breakwater, seawall, revetment) may not be the linear combination of each system acting alone. Therefore further investigation of wave-vegetation-structure interaction is required. Breakpoints, or conditions at which these natural systems fail, in addition to failure criteria for mangrove forests during a design event, must also be defined to identify the limitations of these infrastructures. Complementarily, the resiliency, or ability to rebound after a damaging event of mangrove forest needs to be investigated. Addressing these knowledge gaps may serve as a model for developing guidance for the implementation of other natural features, including marshes, wetlands, and reefs.

In addition to defining the engineering performance of mangrove systems, the interconnected contribution to ecological, biological, and social co-benefits of mangroves and other natural infrastructure must be quantified and considered in cost-benefit analysis to inform decision-makers considering multiple gray and green design alternatives. Similarly, existing social norms and policy effects on shoreline management must be addressed to improve community education and buy-in to implement natural and nature-based shoreline protection.

CONCLUSIONS: This EWN TN presents a literature review of mangrove ecosystems and their potential for coastal protection through wave attenuation and erosion prevention. Previous field observations from historic tsunami and tropical cyclone events, combined with investigations through field observations and physical modeling, indicate that these systems mitigate inland hydrodynamic conditions and loads on near-coast structures, protecting life safety and mitigating damage to structures in coastal communities. Additional work is required to define and quantify 
performance metrics for these systems to develop practical design guidance for implementing mangroves in appropriate environments.

ADDITIONAL INFORMATION: This EWN TN was prepared as part of Wave Attenuation of Coastal Mangroves During Extreme Water Levels at Near Prototype Scales work unit in the Flood and Coastal $(F \& C)$ R\&D Program and Engineering with Nature (EWN) initiative under the Dredging Operations and Environmental Research Program, and was written by Nia Hurst (Nia.R.Hurst@usace.army.mil), Duncan B. Bryant (Duncan.Bryant@usace.army.mil), and Leigh Provost (Leigh.A.Provost@erdc.dren.mil) of the US Army Engineer Research and Development Center (ERDC) in collaboration with Tori Tomiczek (vjohnson@usna.edu) and Anna Wargula (wargula@usna.edu) of the US Naval Academy. The Program Managers are Dr. Brandon Boyd $(\mathrm{F} \& \mathrm{C})$ and Dr. Jeff King (EWN). This EWN TN should be cited as follows:

Tomiczek, T., A. Wargula, N. R. Hurst, D. B. Bryant, and L. A. Provost. Engineering With Nature: The Role of Mangroves in Coastal Protection. ERDC/TN EWN-21-1. Vicksburg, MS: US Army Engineer Research and Development Center. http://dx.doi.org/10.21079/11681/42420

\section{REFERENCES}

Alongi D. M. 2008. "Mangrove Forests: Resilience, Protection from Tsunamis, and Responses to Global Climate Change." Estuar. Coast. Shelf Sci. 76(1): 1-13. doi:10.1016/j.ecss.2007.08.024.

Alongi, D. M. 2014. "Carbon Cycling and Storage in Mangrove Forests." Annual Review Marine Science 2014(6): $195-219$.

Anderson, M. E., and J. M. Smith. 2014. "Wave Attenuation by Flexible, Idealized Salt Marsh Vegetation." Coast. Eng. 83: 82-92.

Anderson, M. E., J. M. Smith, and S. K. McKary. 2011. Wave Dissipation by Vegetation. ERDC/CHL CHETN-I-82. Vicksburg, MS: US Army Engineer Research and Development Center.

Armitage, A. R., C. A. Weaver, J. S. Kominoski, and S. C. Pennings. 2020. "Resistance to Hurricane Effects Varies Among Wetland Vegetation Types in the Marsh-Mangrove Ecotone." Estuaries and Coasts 43: 960-970.

Asbridge, E., R. Lucas, K. Rogers, and A. Accad. 2018. "The Extent of Mangrove Change and Potential for Recovery Following Severe Tropical Cyclone Yasi, Hinchinbrook Island, Queensland, Australia." Ecol. Evol. 8: 10416-34.

Baldwin, A., M. Egnotovich, M. Ford, and W. J. Platt. 2004. "Regeneration in Fringe Mangrove Forests Damaged by Hurricane Andrew." Plant Ecology 157: 151-164.

Bao, T. Q. 2011. "Effect of Mangrove Forest Structures on Wave Attenuation in Coastal Vietnam." Oceanologia 53(3): 807-808.

Breithaupt, J. L., N. Hurst, H. E. Steinmuller, E. Duga, J. M. Smoak, J. S. Kominoski, and L. G. Chambers. 2019. "Comparing the Biogeochemistry of Storm Surge Sediments and Pre-Storm Soils in Coastal Wetlands:

Hurricane Irma and the Florida Everglades." Estuaries and Coasts 1-14. https://doi.org/10.1007/s12237-019$\underline{00607-0}$

Breithaupt, J. L., J. M. Smoak, V. H. Rivera-Monroy, E. Castañeda-Moya, R. P. Moyer, M. Simard, and C. J. Sanders. 2017. "Partitioning the Relative Contributions of Organic Matter and Mineral Sediment to Accretion Rates in Carbonate Platform Mangrove Soils." Marine Geology 390: 170-180.

https://doi.org/10.1016/j.margeo.2017.07.002 
Breithaupt, J. L., J. M. Smoak, T. S. Bianchi, D. Vaughn, C. Sanders, K. R. Radabaugh, M. Osland, L. C. Feher, J. Lynch, D. R. Cahoon, G. H. Anderson, K. R. Whelan, B. Rosenheim, R. Moyer, and L. Chambers. 2020. "Increasing Rates of Carbon Burial in Southwest Florida Coastal Wetlands." Journal of Geophysical Research 125.

Bridges, T. S., E. M. Bourne, J. K. King, H. K. Kuzmitski, E. B. Moynihan, and B. C. Suedel. 2018. Engineering With Nature: An Atlas. ERDC/EL SR-18-8. Vicksburg, MS: US Army Engineer Research and Development Center. http://dx.doi.org/10.21079/11681/27929

Cavanaugh, K. C., J. R. Kellner, A. J. Forde, D. S. Gruner, J. D. Parker, W. Rodriguez, and I. C. Feller. 2013. "Poleward Expansion of Mangroves is a Threshold Response to Decreased Frequency of Extreme Cold Events. Proceedings of the National Academy of Sciences 111: 723-727.

Chang, C. W., N. Mori, N. Tsuruta, and K. Suzuki. 2019. "Estimation of Wave Force Coefficients on Mangrove Models." Journal of Japan Society of Civil Engineers Ser. B2 (Coastal Engineering). 75, 2, I_1105-I_1110. https://doi.org/10.2208/kaigan.75.I_1105.

Chang, S. E., B. J. Adams, J. Alder, P. R. Berke, R. Chuenpagdee, S. Ghosh, and C. Wabnitz. 2006. "Coastal Ecosystems and Tsunami Protection after the December 2004 Indian Ocean Tsunami." Earthquake Spectra 22: S863eS887.

Cheong, S. M., B. Silliman, P. P. Wong, B. van Wesenbeeck, C. K. Kim, and G. Guannel. 2013. "Coastal Adaptation with Ecological Engineering." Nature Climate Change 3(2013): 787-791.

Chmura, G. L., S. C. Anisfeld, D. R. Cahoon, and J. C. Lynch. 2003. "Global Carbon Sequestration in Tidal, Saline Wetland Soils." Global Biogeochem.Cycles 17(4): 1111. doi:10.1029/2002GB001917.

Clough, B., M. Phillips, and T. T. Xuan. 1999. Termination Report, PN 9412: Mixed Shrimp Farming Mangrove Forestry Models in the Mekong Delta. Australian Institute of Marine Science.

Dalrymple, R. A., J. T. Kirby, and P. A. Hwang. 1984. "Wave Diffraction Due to Areas of Energy Dissipation." Journal of Waterway, Port, Coastal, and Ocean Engineering 110(1): 67-79.

Danielsen, F., M. K. Sørenson, M. F. Olwig, V. Selvam, F. Parish, N. D. Burgess, T. Hiraishi, V. M. Karunagaran, M. S. Rasmussen., L. B. Hansen, A. Quarto, and N. Suryadiputra. 2005. "The Asian Tsunami: A Protective Role for Coastal Vegetation." Science 310(5748): 643. doi: 10.1126/science.1118387.

Danielson, T. M., V. H. Rivera-Monroy, E. Castañeda-Moya, H. Briceño, R. Travieso, B. D. Marx, E. Gaiser, and L. M. Farfán. 2017. "Assessment of Everglades Mangrove Forest Resilience: Implications for Above-Ground Net Primary Productivity and Carbon Dynamics." Forest Ecology and Management 404(2017): 115-125. doi: Forest Ecology and Management.

Das, S., and J. R. Vincent. 2009. "Mangroves Protected Villages and Reduced Death Toll during Indian Super Cyclone." PNAS 106: 18: 7357-7360.

Dawes, C., K. Siar, and D. Marlett. 1999. "Mangrove Structure, Litter, and Macroalgal Productivity in a NorthernMost Forest of Florida." Mangroves and Salt Marshes 3: 259-267.

Donato, D., J. Kauffman, and D. Murdiyarso. 2011. "Mangroves among the Most Carbon-Rich Forests in the Tropics." Nature Geosci 4: 293-297. https://doi.org/10.1038/ngeo1123.

Doughty, C. L., J. A. Langley, and W. S. Walker. 2016. "Mangrove Range Expansion Rapidly Increases Coastal Wetland Carbon Storage." Estuaries and Coasts 39: 385-396. https://doi.org/10.1007/s12237-015-9993-8

EAD (Environmental Agency - Abu Dhabi). 2015. EAD-TMBS-TG-01: Technical Guidance Document for Mangrove Planting Permitting and Management Plan. Environmental Agency - Abu Dhabi.

Ellison, A. M. 2002. "Macroecology of Mangroves: Large-Scale Patterns and Processes in Tropical Coastal Forests." Trees Struct Funct 16: 181-194.

FDEP (Florida Department of Environmental Protection). 2019. Florida's Mangroves. https://floridadep.gov/rcp/rcp/content/floridas-mangroves 


\section{ERDC/TN EWN-21-1}

\section{November 2021}

Feller, C. 2018. "Mangroves. The Ocean Portal Team." Smithsonian, April, 2018. https:/locean.si.edu/oceanlife/plants-algae/mangroves.

Feller, C., and M. Sitnik. 1996. Mangrove Ecology Workshop Manual. Smithsonian Institution, Washington, DC.

Friess, D. A., K. Rogers, C. E. Lovelock, K. W. Krauss, S. E. Hamilton, S. Y. Lee, R. Lucas, J. Primavera, A. Rajkaran, and S. Shi. 2019. "The State of the World's Mangrove Forests: Past, Present, and Future." Annual Review of Environmental Resources 44: 89-115

Fujimoto, K., A. Imaya, and R. Tabuchi. 1999. "Belowground Carbon Storage of Micronesian Mangrove Forests." Ecol Res 14: 409-413. https://doi.org/10.1046/j.1440-1703.1999.00313.x

Furukawa, K., and E. Wolanski. 1996. "Sedimentation in Mangrove Forests." Mangroves and Salt Marshes 1: 3-10. https://doi.org/10.1023/A:1025973426404

Furukawa, K., E. Wolanski, and H. Mueller. 1997. "Currents and Sediment Transport in Mangrove Forests." Estuarine, Coastal and Shelf Science 44: 301-310. https://doi.org/10.1006/ecss.1996.0120

Gilman, E. L., J. Ellison, N. C. Duke, and C. Field. 2008. "Threats to Mangroves from Climate Change and Adaptations Options: A Review." Aquatic Botany 89: 238-250. doi:10.1016/j.aquabot.2007.12.009

Giri, C., and J. Long. 2016. "Is the Geographic Range of Mangrove Forests in the Conterminous United States Really Expanding? Sensors (Basel. 16(12): 2010. doi:10.3390/s16122010.

Giri, C. P., and J. B. Long. 2014. "Mangrove Reemergence in the Northernmost Range Limit of Eastern Florida." Proceedings of the National Academy of Sciences 111: E1447-E1448.

Giri, C., E. Ochient, L. L. Tieszen, Z. Zhu, A. Singh, T. Loveland, J. Masek, and N. Duke. 2011. "Status and Distribution of Mangrove Forests of the World Using Earth Observation Satellite Data." Global Ecology and Biogeography 20: 154-159. doi: 10.1111/j.1466-8238.2010.005864.x.

Goda K., N. Mori, T. Yasuda, A. Prasetyo, A. Muhammad, and D. Tsujio. 2019. "Cascading Geological Hazards and Risks of the 2018 Sulawesi Indonesia Earthquake and Sensitivity Analysis of Tsunami Inundation Simulations. Front." Earth Sci 7:261. doi: 10.3389/feart.2019.00261.

Guannel, G., K. Arkema, P. Ruggiero, and G. Verutes. 2016. "The Power of Three: Coral Reefs, Seagrasses and Mangroves Protect Coastal Regions and Increase Their Resilience." PLoSONE 11(7).

Horstman, E. M., C. M. Dohmen-Janssen, P. M. F. Narra, N. J. F. van den Berg, M. Siemerink, and S. J. M. H. Hulscher. 2014. "Wave Attenuation in Mangroves: A Quantitative Approach to Field Observations." Coastal Engineering 94(2014): 47-62.

Houck, M. J., and R. H. Neil. 2009. "Plant Fact Sheet for Black Mangrove (Avicennia germinans)." USDA-Natural Resources Conservation Service, Louisiana Plant Materials Center, Galliano, LA 70354.

Huang, Z., Y. Yao, S. Y. Sim, and Y. Yao. 2011. "Interaction of Solitary Waves with Emergent, Rigid Vegetation." Ocean Engineering 38: 1080-1088.

Hussain, S. A., and R. Badola. 2010. "Valuing Mangrove Benefits: Contribution of Mangrove Forests to Local Livelihoods in Bhitarkanika Conservation Area, East Coast of India." Wetlands Ecol Manage 18: 321-331. https://doi.org/10.1007/s11273-009-9173-3

Imbert, D., A. Rousteau, and P. Scherrer. 2000. "Ecology of Mangrove and Recovery in the Lesser Antilles: State of Knowledge and Basis for Restoration Projects." Restoration Ecology 8: 230-236.

Irish, J. L., R. Weiss, Y. Yang, Y. K. Song, A. Zainali, and R. Marivela-Colmenarejo. 2014. "Laboratory Experiments of Tsunami Run-Up and Withdrawal in a Patchy Coastal Forest on a Steep Beach." Nat. Hazards 74: 1933-1949.

Ismail, I., M. L. Husain, and R. Zakaria. 2017. "Attenuation of Waves from Boat Wakes in Mixed Mangrove Forest of Rhizophora and Bruguiera Species in Matang, Perak." Malaysian Journal Geosciences 1(2): 29-32.

Jin Eong, O., G. W. Khoon, and B. F. Clough. 1995. "Structure and Productivity of a 20-Year-Old Stand of Rhizophora apiculata Bl. Mangrove Forest." Journal of Biogeography 22: 417-424. 
Kainuma, M., S. Baba, N. Oshiro, M. Kezuka, and H. T. Chan. 2013. "The Current Status of Mangroves Worldwide." Global Environmental Research 17(2013): 147-154.

Kathiresan, K. 2003. "How Do Mangrove Forests Induce Sedimentation?” Revista de Biología Tropical 51(2): 355360.

Kalloe, S. 2019. Wave Damping Potential of woody Riparian Vegetation: Comparing Terrestrial Laser Scanning with Manual Measuring Techniques. 2019. Delft University of Technology. http://resolver.tudelft.nl/uuid:6e9c1f7a4ef9-48ef-bb97-796a9b74fe6b

Krauss, K. W., J. A. Allen, and D. R. Cahoon. 2003. "Differential Rates of Vertical Accretion and Elevation Change among Aerial Root Types in Micronesian Mangrove Forests." Estuarine, Coastal and Shelf Science 56(2): 251259.

Krauss, K. W., and M. C. Ball. 2013. "On the Halophytic Nature of Mangroves." Trees 27: 7-11.

Krauss, K. W., T. W. Doyle, T. J. Doyle, C. M. Swarzenski, A. S. From, R. H. Day, and W. H. Conner. 2009. "Water Level Observations in Mangrove Swamps during Two Hurricanes in Florida." Wetlands 29(1): 142-149.

Kumara, M. P., L. P. Jayatissa, K. W. Krauss, D. H. Phillips, and M. Huxham. 2010. "High Mangrove Density Enhances Surface Accretion, Surface Elevation Change, and Tree Survival in Coastal Areas Susceptible to Sealevel Rise." Oecologia 164: 545-553.

Lara, J. L., M. Maza, B. Ondiviela, J. Trinogga, I. J. Losada, T. J. Bouma, and N. Gordejuela. 2016. "Large-Scale 3D Experiments of Wave and Current Interaction with Real Vegetation. Part 1: Guidelines for Physical Modeling." Coastal Engineering 107: 70-83.

Lei, J., and H. Nepf. 2019. "Wave Damping by Flexible Vegetation: Connecting Individual Blade Dynamics to the Meadow Scale." Coastal Engineering 147(2019): 138-148.

Lewis, R. R., R. G. Gilmore Jr., D. W. Crewz, and W. E. Odum. 1985. "Mangrove Habitat and Fishery Resources of Florida." Pages 281-336 in Florida Aquatic Habitat and Fishery Resources. Edited by W. Seaman, Jr. American Fisheries Society.

Long, Jordan, C. Giri, J. Primavera, and Mandar Trivedi. "Damage and Recovery Assessment of the Philippines' Mangroves Following Super Typhoon Haiyan." Marine Pollution Bulletin 109(2) (2016): 734-43.

Lovelock, C. E., K. Kraus, M. J. Osland, R. Reef, and M. C. Ball. 2019. "The Physiology of Mangrove Trees with Changing Climate." Tropical Tree Physiology: Adaptations and Responses in a Changing Environment. Edited by G. H. Goldstein and L. S. Santiago. New York, NY: Springer.

Lugo, A. E., and S. C. Snedaker. 1974. "The Ecology of Mangroves." Annual Rev. Ecol. Syst. 1974(5): 39-64.

Maza, M., J. L. Lara, and I. J. Losada. 2015. "Tsunami Wave Interaction with Mangrove Forests: A 3D Numerical Approach." Coastal Engineering 98(2015): 33-54.

Maza, M., J. L. Lara, and I. J. Losada. 2016. "Solitary Wave Attenuation by Vegetation Patches." Advances in Water Resources 98(2016): 159-172.

Maza, M., K. Adler, D. Ramos, A. M. Garcia, and H. Nepf. 2017. "Velocity and Drag Evolution from the Leading Edge of a Model Mangrove Forest." J. Geophysical Research: Oceans 122. DOI 10.1002/2017JC012945.

Maza, M., J. L. Lara, and I. J. Losada. 2019. "Experimental Analysis of Wave Attenuation and Drag Forces in a Realistic Fringe Rhizophora Mangrove Forest." Advances in Water Resources 131(2019): 103376.

Mazda Y., M. Magi, M. Kogo, and P. N. Hong. 1997. "Mangroves as a Coastal Protection from Waves in the Tong King Delta, Vietnam." Mangr. Salt Marsh 1(2): 127-135. doi:10.1023/A:1009928003700.

McLeod, E., and R. V. Salm. 2006. Managing Mangroves for Resilience to Climate Change. Gland, Switzerland: IUCN.

McLeod, E., G. L. Chmura, S. Bouillon, R. Salm, M. Bjork, C. M. Duarte, C. E. Lovelock, W. H. Schlesinger, and B. R. Silliman. 2011. "A Blueprint for Blue Carbon: Toward an Improved Understanding of the Role of Vegetated Coastal Habitats in Sequestering CO2." Frontiers in Ecology and the Environment 9: 552-560. 


\section{ERDC/TN EWN-21-1}

November 2021

Mendelssohn I. A., and K. L. McKee. 2000. "Salt Marshes and Mangroves." North American Terrestrial Vegetation. Edited by M. G. Barbour and W. D. Billings. Cambridge: Cambridge University Press.

Mendez, F. J., and I. J. Losada. 2004. "An Empirical Model to Estimate the Propagation of Random Breaking and Non-Breaking Waves over Vegetation Fields." Coastal Engineering 52: 103-118.

Narayan, S., M. W. Beck, B. G. Reguero, I. J. Losada, B. van Wesenbeeck, N. Pontee, J. N. Sanchirico, J. C. Ingram, G. M. Lange, and K. A. Burks-Copes. 2016. "The Effectiveness, Costs, and Coastal Protection Benefits of Natural and Nature-Based Defences." PLoS ONE 11(5): 17.

Narayan, S., C. Thomas, J. Matthewman, C. Shepard, L. Geselbracht, K. Nzerem, and M. Beck. 2019. Valuing the Flood Risk Reduction Benefits of Florida's Mangroves. UC Santa Cruz, RMS, Nature Conservancy.

NAS (National Academy of Sciences). 1977. Methodology for Calculating Wave Action Effects Associated with Storm Surges. Washington, DC.

Nepf, H. 1999. "Drag, Turbulence, and Diffusion in Flow through Emergent Vegetation." Water Resource Research 35(2): 479-489.

Novitarima A., and T. D. Saputri. 2019. "Reducing Tsunami Wave Energy by Mangrove Ecosystem Based on Tsunami Inundation Model in Palu Timur, Indonesia." 16th Hokkaido Indonesian Student Association Scientific Meeting, Sapporo, Japan, August 2019.

Novitzky, P. 2010. Analysis of Mangrove Structure and Latitudinal Relationships on the Gulf Coast of Peninsular Florida. University of South Florida.

Odum, W. E., C. C. McIvor, and T. S. Smith. 1982. The Ecology of Mangroves of South Florida: A Community Profile. FWS/OBS - 81/24. Washington, DC: U.S. Fish and Wildlife Service, Office of Biological Services.

Ohira, W., K. Honda, M. Nagai, and A. Ratanasuwan. 2013. "Mangrove Stilt Root Morphology Modelling for Estimating Hydraulic Drag in Tsunami Inundation Simulation." Trees 27: 141-148.

Ozeren, Y., D. G. Wren, and W. Wu. 2014. "Experimental Investigation of Wave Attenuation through Model and Live Vegetation." J. Waterway, Port, Coastal, and Ocean Eng. 140(5): 04014019.

Quartel, S., A. Kroon, P. Augustinus, P. van Santen, and N. H. Tri. 2007. "Wave Attenuation in Coastal Mangroves in the Red River Delta, Vietnam." J. Asian Earth Sciences 29(4): 576-584. doi: 10.1016/j.jseaes.2006.05.008.

Quisthoudt, K., N. Schmitz, C. F. Randin, F. Dahdouh-Guebas, E. M. R. Robert, and N. Koedam. 2012. "Temperature Variation among Mangrove Latitudinal Range Limits Worldwide." Trees 2012(26): 1919-1931. doi: 10.1007/s00468-012-0760-1.

Reef, R., and C. E. Lovelock. 2015. "Regulation in Water Balance in Mangroves." Annals of Botany 115(3): 385-395.

Reinisch, L. L. 2014. Once There Were Fishermen: Social Natures, Environmental Ethics, and an Urban Mangrove. University of Manchester.

Saintilan, N., N. S. Khan, E. Ashe, J. J. Kelleway, K. Rogers, C. D. Woodroffe, and B. P. Horton. 2020. "Thresholds of Mangrove Survival under Rapid Sea Level Rise." Science 368(6495): 1118-1121. doi: 10.1126/science.aba2656.

Situmorang, R. O. P. 2018. "Social Capital in Managing Mangrove Ecotourism Area by the Muara Baimbai Community." Indonesian J. Forestry Research 5(1): 21-34.

Spalding, M. D., M. Kainuma, and L. Collins. 2010. World Atlas of Mangroves. London: Earthscan.

Steinmuller, H. E, T. E. Foster, P. Boudreau, C. R. Hinkle, and L. G. Chambers. 2019. "Tipping Points in the Mangrove March: Characterization of Biogeochemical Cycling along the Mangrove-Salt Marsh Ecotone," Ecosystems, 23: $417-434$.

Strusińska-Correia, A., S. Husrin, and H. Oumeraci. 2013. "Tsunami Damping by Mangrove Forest: A Laboratory Study Using Parameterized Trees." Nat. Hazards Earth Syst. Sci. 13: 483-503. doi:10.5194/nhess-13-483-2013. 
Taillie, P. J., R. Roman-Cuesta, D. Lagomasino, M. Cifuentes-Jara, T. Fatoyinbo, L. E. Ott, B. Poulter. 2020. Widespread Mangrove Damage Resulting from the 2017 Atlantic Mega Hurricane Season. Environmental Research Letters 15: 064010.

Tassie, P. J., R. Roman-Cuestra, D. Lagomasino, M. Cifuentes-Jara, T. Fatoynbo, L. E. Ott, and B. Poulter. 2020. "Widespread Mangrove Damage Resulting from the 2017 Atlantic Mega Hurricane Season." Environ. Res. Lett. 15: 064010 .

Thuy, N. B., N. A. K. Nandasena, V. H. Dang, S. Kim, N. X. Hien, L. R. Hole, and T. H. Thai. 2017. "Effect of River Vegetation with Timber Piling on ship Wave Attenuation: Investigation by Field Survey and Numerical Modeling." Ocean Engineering 129(2017): 37-45.

Tomiczek, T., A. Wargula, M. Jendrysik, S. Goodwin, A. B. Kennedy, P. Lynett, P. Lomonaco, and D. T. Cox. 2019. "Physical Model Investigation of Parcel-Scale Effects of Mangroves on Wave Transformation and Force Reduction in the Built Environment." Coastal Structures Proceedings, September 28-October 2, 2019, Hannover, Germany.

Tomiczek, T., K. O'Donnell, K. Furman, B. Webbmartin, and S. Scyphers. 2020a. "Rapid Damage Assessments of Shorelines and Structures in the Florida Keys after Hurricane Irma." Natural Hazards Review 21(1). doi: 10.1061/(ASCE)NH.1527-6996.0000349.

Tomiczek, T., A. Wargula, P. Lomonaco, S. Goodwin, D. Cox, A. Kennedy, and P. Lynett. 2020b. "Physical Model Investigation of Mid-Scale Mangrove Forest Effects on Flow Hydrodynamics, Pressures, and Loads in the Built Environment." Coastal Engineering, Revisions submitted.

Tomlinson, P. B. 1986. The Botany of Mangroves. Cambridge, UK: Cambridge University Press.

Trung, V. L., J. Yagisawa, and N. Tanaka. 2015. "Efficacy of Rhizophora apiculata and Nypa Fruticans on Attenuation of Boat-Generated Waves under Steep Slope Condition." Int. J. Ocean Water Resour. 19(2): 11031114.

Ueland, J. S. 2005. Ecological Modeling and Human Dimensions of Mangrove Change in Florida. Florida State University.

USFWS (U.S. Fish and Wildlife Service). 1999. South Florida Multi-Species Recovery Plan. Atlanta, Georgia.

Vo, Q. T., C. Kuenzer, Q. M. Vo, F. Moder, and N. Oppelt. 2012. "Review of Valuation Methods for Mangrove Ecosystem Services." Ecological Indicators 23(2012): 431-446.

Vo-Luong, P. H., and S. R. Massel. 2006. "Experiments on Wave Motion and Suspended Sediment Concentration at Nang Hai, Can Gio Mangrove Forest, Southern Vietnam." Oceanologia 48(1): 23-40.

Vo-Luong, P., and S. Massel. 2008. "Energy Dissipation in Non-Uniform Mangrove Forest of Arbitrary Depth." Journal of Marine Systems 74: 603-622.

Wang, W., Z. Yan, Y. Zhang, L. Chen, and G. Lin. 2011. "Mangroves: Obligate or Facultative Halophytes? A Review." Trees 25: 953-963.

Zhang, X., V. P. Chua, and H. F. Cheonf. 2015. "Hydrodynamics in Mangrove Prop Roots and Their Physical Properties." Journal of Hydro-Environment Research 9: 281-294.

Zhang, K., H. Liu, Y. Li, H. Xu, J. Shen, J. Rhome, and T. J. Smith III. 2012. "The Role of Mangroves in Attenuating Storm Surges." Estuarine, Coastal, and Shelf Science 102-103(2012): 11-23.

NOTE: The contents of this technical note are not to be used for advertising, publication, or promotional purposes.

Citation of trade names does not constitute an official endorsement or approval of the use of such products. 